$\boldsymbol{\nabla}$ Artikkeli

\title{
Kolmikantaisten valmisteluryhmien julkisuussäännöt: tapaustutkimus Sosiaaliturvan uudistamiskomiteasta
}

\begin{abstract}
Poliittisissa instituutioissa on julkisuussääntöjä eli päättäjien keskinäisiä sääntöjä siitä, miten mediajulkisuudessa saa toimia. Tällaisia sääntöjä ei ole kuitenkaan aiemmin varsinaisesti tutkittu. Ei esimerkiksi tiedetä, miten vakiintuneita julkisuussäännöt ovat ja missä määrin ne todella selittävät julkisuudessa toimimista. Artikkelissa tutkimme empiirisesti, millaisia julkisuussääntöjä on kolmikantaisissa valmistelutyöryhmissä, ja miten nämä säännöt vaikuttavat päätöksenteon läpinäkyvyyteen ja mediajulkisuudessa toimimiseen. Tutkimme tätä ensisijaisesti Sata-komitean (2007-2009) jäsenten haastattelujen avulla. Kolmikantaisissa valmisteluryhmissä on monia julkisuussääntöjä, jotka koskevat esimerkiksi keskustelujen ja asiakirjojen luottamuksellisuutta sekä omien tavoitteiden esittelemistä julkisuudessa. Osa säännöistä koskee vain tietyssä roolissa toimivia henkilöitä. Julkisuussäännöt vaikuttivat siihen, että Sata-komitean työhön kohdistui sanomalehdissä sen lopullisiin esityksiin nähden päinvastaisia odotuksia. Julkisuussäännöt eivät kuitenkaan selitä kolmikantavalmistelijoiden toimintaa mediajulkisuudessa kovin vahvasti. Sääntöjen rikkominen on tyypillistä ja kaikki säännöt eivät ole täysin vakiintuneita.
\end{abstract}

AVAINSANAT: julkisuudenhallinta, julkinen keskustelu, säännöt, instituutiot, kolmikanta, valmistelu, päätöksenteko.

U

udistusten valmistelulla kolmikannassa hallituksen, palkansaajien ja työnantajien kesken on Suomessa pitkät perinteet. Komiteat ovat olleet kolmikantaisen valmistelun keskeinen areena. Vaikka kolmikannan asema on viime vuosikymmeninä muuttunut, ja komiteoiden määrä on vähentynyt lähes olemattomaksi (Rainio-Niemi 2010, 260-262; Pakarinen 2011a, 50; 2011b, 55-58), monet esimerkiksi sosiaaliturvaan, työeläkkeisiin ja työlainsäädäntöön liittyvät uudistukset valmistellaan edelleen kolmikantaisissa komiteoissa tai työryhmissä (Tiitinen 2007; Hannikainen \& Vauhkonen 2012; Kananen 2014).' Kolmikantaisiin valmisteluryhmiin liittyvää mediajulkisuutta ei ole Suomessa juuri tutkittu (ks. kuitenkin Pulkkinen 2011). Ylipäätään 
valmistelun ja mediajulkisuuden välistä suhdetta on tutkittu Suomessa varsin vähän (Kunelius ym. 2010, 422-447; Kuutti 2011, 267-272, 496-502).

Tässä artikkelissa tarkastelemme, millaisia julkisuussääntöjä kolmikantaisiin valmisteluryhmiin mahdollisesti liittyy. Päättäjien toimintaa mediajulkisuudessa on selitetty aiemmin muun muassa median toimintatavoilla (esim. Mazzoleni \& Schulz 1999; Spörer-Wagner \& Marcinkowski 2010) sekä päättäjien ja toimittajien välisen vuorovaikutuksen normeilla ja pelisäännöillä (esim. Blumler \& Gurevitch 1995, 36-39; Pfetsch 2004). Myös päättäjien välisten verkostojen ja poliittisten instituutioiden rakenteiden on nähty kannustavan päättäjiä toimimaan mediajulkisuudessa tietyillä tavoilla (Sigal 1973, 131-133; Cook 1998; Kriesi 2004). Sen sijaan vähemmälle huomiolle on jäänyt kysymys siitä, missä määrin poliittisiin instituutioihin liittyvät päättäjien keskinäiset, julkisuudessa toimimista koskevat säännöt mahdollisesti selittävät politiikan julkisuutta. Tällaiset julkisuussäännöt on mainittu ohimennen muutamissa tutkimuksissa tai teoreettisissa katsauksissa (esim. Kantola 2002; Kriesi 2004; Kunelius ym. 2010; Brown 2011), mutta sääntöjä sinänsä ei ole tietääksemme varsinaisesti tutkittu. Kysymme, onko poliittisissa instituutioissa vakiintuneita, institutionalisoituneita julkisuussääntöjä, ja missä määrin säännöt selittävät päätösvalmisteluun liittyvää mediajulkisuutta. Tarkastelemme julkisuussääntöjä instituutioteorian näkökulmasta (erityisesti Hodgson 2006 ja 2007).

Tutkimme aihetta ensisijaisesti Sosiaaliturvan uudistamiskomitean eli Sata-komitean (2007-2009) kautta. Sosiaaliturvan kokonaisuudistusta ${ }^{2}$ tavoitellut komitea kuului pääministeri Matti Vanhasen toisen hallituksen kärkihankkeisiin. Komitean tavoitteena oli "työn kannustavuuden parantaminen, köyhyyden vähentäminen sekä riittävän perusturvan tason turvaaminen kaikissa elämäntilanteissa" (STM 2007). Komiteaa voi pitää kolmikantaisena, koska kolmikannan osapuolet olivat Sata-komiteassa vahvasti edustettuina, ja ne olivat sen päätöksenteossa erittäin keskeisessä asemassa (Saari 2009, 245). ${ }^{3}$

Tarkastelemme Sata-komitean kautta myös sitä, miten julkisuussäännöt vaikuttavat päätöksenteon läpinäkyvyyteen. Toisen maailmansodan jälkeen muodostuneen sosiaaliturvan eräs alkuperäinen tarkoitus on ollut jakaa uudelleen tuloja ja turvata elintaso. 1990-luvulta lähtien sosiaaliturvan tasoa on kuitenkin madallettu, saantiehtoja tiukennettu ja sanktioita kiristetty. Näitä muutoksia on perusteltu tarpeella lisätä työvoiman tarjontaa (vrt. Vartiainen 2013). Sosiaaliturva on näin haluttu tehdä "kannustavaksi". Tavoitteet on kytketty vientiyritysten tarpeisiin tehdä kilpailukykyisiä tuotteita mahdollisimman pienin työvoimakustannuksin. (Julkunen 2001; Kantola \& Kananen 2013.) Sata-komitean lopputulos oli pääosin yhdenmukainen tämän 1990luvun alussa aloitetun poliittisen suunnan kanssa. Kustannusvaikutukseltaan selvästi suurin Sata-komitean yhteydessä tehty päätös oli työnantajien sosiaaliturvamaksujen (niin sanotun KELA-maksun) poisto ${ }^{4}$. Pienituloisten asemaa parannettiin muun muassa korottamalla kunnallisveron perusvähennystä, asettamalla eläkkeelle minimimäärä sekä sitomalla lapsilisä, kotihoidon tuki ja sairausvakuutuksen vähimmäispäiväraha elinkustannusindeksiin (vrt. Honkanen \& Tervola 2012, 5). Huomattavasti enemmän rahaa kuitenkin käytettiin yritysten työvoimakustannusten pienentämi- 
seen. Tuloja uudelleen jakavalla ja köyhyyttä ehkäisevällä sosiaaliturvalla on kuitenkin pitkään ollut Suomessa kansalaisten enemmistön kannatus (Muuri \& Mandelbacka 2010), ja mediajulkisuudessa moni oletti Sata-komitean työn alkuvaiheessa, että komitea tekee erityisesti juuri sosiaalista eriarvoisuutta vähentäviä päätöksiä. Komitean julkisuuskuva oli siis osittain harhaanjohtava. ${ }^{5}$ Tarkastelemme, missä määrin julkisuussäännöt mahdollisesti selittävät tätä komitean julkisuuskuvan ja lopputuloksen välistä ristiriitaa.

\section{Instituutiot sääntöjen järjestelminä}

Käsityksemme instituutioiden säännöistä nojaa vahvasti Geoffrey Hodgsoniin (2007, 96), jonka mukaan instituutiot ovat "vakiintuneiden ja juurtuneiden sosiaalisten sääntöjen järjestelmiä, jotka tuovat rakennetta sosiaaliseen vuorovaikutukseen". Nämä säännöt ovat "sosiaalisesti välittyneitä ja tavanmukaisia normatiivisia velvoitteita tai immanentisti normatiivisia taipumuksia tehdä $Y$ olosuhteissa X" (emt.). ${ }^{6}$ Hodgsonin käsitys säännöistä on siten laaja. Sääntöjen ei tarvitse esimerkiksi lakien tavoin olla eksplisiittisiä, ääneen lausuttuja tai paperille kirjoitettuja, vaan niiden noudattaminen perustuu ennen kaikkea sosiaalisessa toiminnassa opittuihin taipumuksiin toimia tietyllä tavalla tietyssä tilanteessa. (Hodgson 2006, 3-8; Hodgson 2007, 106-107.) Ihmiset omaksuvat näitä taipumuksia esimerkiksi toiston kautta ja imitoimalla muita inmisiä (Hodgson 2007, 107).

Hodgsonin määritelmä eroaa niistä teorioista, joiden mukaan instituutiot koostuvat ennen kaikkea sellaisista säännöistä (kuten lait), joiden rikkominen johtaa selkeästi määriteltyihin sanktioihin (vrt. Scott 2008, 52-54). Hodgsonin $(2006,6)$ mukaan pelkkä lain (ja niissä määriteltyjen sanktioiden) olemassaolo ei vielä tee siitä institutionaalista sääntöä. Lakia voidaan pitää institutionaalisena sääntönä vain, jos ihmisillä on taipumus noudattaa sitä. Tämä ei kuitenkaan tarkoita sitä, että sääntö lakkaisi olemasta, jos sitä silloin tällöin rikotaan.

Instituutioiden sääntöjä ei pidä ymmärtää toimintaa täysin determinoiviksi rakenteiksi, vaan ne jättävät aina jossain määrin tilaa myös yksilölliselle käyttäytymiselle: instituutioiden säännöt ovat usein tulkinnanvaraisia ja monimerkityksisiä, ja niistä ei siten voi yleensä suoraan ennustaa käyttäytymistä (March \& Olsen 1989, 22, 24; ks. myös Lawrence ym. 2011, 54 ). Instituutiot myös eroavat sen suhteen, miten vahvasti ne vaikuttavat yksilöiden käyttäytymiseen ja miten paljon ne antavat yksilöpsykologisten tekijöiden kuten persoonallisuuden ohjata käyttäytymistä (Hodgson 2006, 16-17).

Instituutioissa kaikkien ihmisten käyttäytymistä eivät yleensä koske samat säännöt vaan säännöt riippuvat usein siitä, millaisessa roolissa kukin toimii. Roolit perustuvat normatiivisiin velvoitteisiin toimia tietyllä tavalla tai kognitiivisiin käsityksiin siitä, miten tietyssä asemassa olevat inmiset toimivat. (Scott 2008, 55, 58.)

Sääntöjen olemassaolo ei ole joko-tai-kysymys, vaan sääntöjen vakiintumisessa on usein aste-eroja: toiset säännöt ovat vakiintuneempia kuin toiset (esim. Zucker 
1991, 83). Tietty toimintatapa on vahvimmin vakiintunut eli institutionalisoitunut silloin, kun sitä pidetään itsestään selvänä. Tällöin siitä tulee tapa, jonka toteuttaminen ei juuri vaadi tietoista ajattelua tai keskustelua. (Vrt. Colyvas \& Powell 2006, 309.) Jotta voidaan puhua institutionalisoituneista säännöistä, toimintataipumusten täytyy myös olla tietyssä ryhmässä vallitsevia eli laajasti ryhmään kuuluvien ihmisten sisäistämiä (vrt. Hodgson 2006, 6).

Instituutioiden kulttuurista ja kognitiivista luonnetta korostavat tutkijat (esim. Berger \& Luckmann 2009) pitävät usein puhetapoja ja kielellisiä merkityksiä instituutioiden keskeisenä elementtinä (ks. Gronow 2008, 358-36o; Scott 2008, 56-59). Jotkut tutkijat ovat kritisoineet tällaista käsitystä. He ovat väittäneet, että yksilön taipumus toimia tietyllä tavalla ei yleensä ainakaan ensisijaisesti perustu hänen tuolle toimintatavalle antamiin kielellisiin merkityksiin (esim. Gronow 2008). Vaikka on selvää, että tavanmukaistunut toiminta ei jatkuvasti edellytä kielellistä ajattelua, kielellä ja merkityksillä on kuitenkin tärkeä rooli instituutioiden olemassaolon ja säilymisen kannalta. Instituutioiden säilyminen ja siirtyminen paikasta toiseen edellyttää usein kielen käyttämistä, ja instituutioiden sääntöjen tulee olla ainakin potentiaalisesti ilmaistavissa kielen avulla, jotta säännön rikkominen voidaan tunnistaa yksiselitteisesti (vrt. Hodgson 2006, 3). Instituutioiden tutkimisen kannalta tämä merkitsee sitä, että säännöistä voidaan saada tietoa esimerkiksi haastattelujen avulla (ks. myös Scharpf 1997, 41) ${ }^{7}$

\section{Julkisuussäännöt}

Myös poliittiset instituutiot ovat sääntöjen järjestelmiä. Oletamme, että niissä on myös sellaisia sääntöjä, jotka koskevat mediajulkisuudessa toimimista, esimerkiksi julkisuudenhallintaa. Kutsumme tällaisia sääntöjä julkisuussäännöiksi.

Tarkoitamme poliittisilla instituutioilla tässä virallisia päätöksenteko- ja valmisteluinstituutioita, kuten komiteoita ja muita valmistelutyöryhmiä, eduskunnan valiokuntia sekä valtioneuvostoa. Myös journalismia (esim. Cook 1998 ; ks. toisaalta Hjarvard 2013, 52-54) on pidetty poliittisena instituutiona, mutta rajaamme journalismin säännöt tarkastelun ulkopuolelle. Tarkoitamme julkisuussäännöillä ainoastaan päätöksenteko- ja valmisteluinstituutioihin liittyviä päättäjien keskinäisiä sääntöjä. Käsite ei siis viittaa esimerkiksi toimittajien ja päättäjien keskinäisen vuorovaikutuksen sääntöihin tai normeihin (ks. esim. Blumler \& Gurevitch 1995, 36-39; Pfetsch 2004).

Julkisuussääntöjä ei ole tietääksemme aiemmin otettu systemaattisen tutkimuksen kohteeksi, vaan ne on lähinnä mainittu muutamissa teksteissä (Kantola 2002, 287; Kriesi 2004, 203; Kunelius ym. 2010, 419; Reunanen ym. 2010, 304; Brown 2011, 67-69). Seuraavaksi muodostamme aiempien tutkimusten avulla alustavia oletuksia julkisuussääntöjen luonteesta ja siitä, millaista toimintaa ne saattavat koskea.

Julkisuussäännöt saattavat koskea ensinnäkin sitä, mitkä asiat ovat poliittisissa instituutioissa julkisia. Julkisuutta koskevat lait vaikuttavat tietysti tähän jossain 
määrin, mutta myös epäviralliset säännöt lienevät tässä tärkeitä. Esimerkiksi Anu Kantolan $(2002,287)$ haastattelemat talouspolitiikan päättäjät kertoivat, että eliitin piirissä on epävirallisia sääntöjä, jotka koskevat sitä, mitkä asiat ovat luottamuksellisia (ks. myös Kunelius ym. 2010, 419). Robin Brown (2011, 67, 69) puolestaan väittää Arend Lijphartin $(1968,131-134)$ tutkimukseen nojaten, että salailu on ollut Alankomaissa päättäjien perinteisesti jakama pelisääntö, joka edelleen hillitsee mediajulkisuuden roolia politiikan tekemisessä.

Julkisuussäännöt saattavat vaikuttaa myös siihen, missä määrin ja milloin päättäjät pyrkivät menemään julkisuuteen (Kernell 1997) eli vaikuttamaan poliittisiin päätöksiin hakemalla mediajulkisuuden kautta kannatusta omille tavoitteilleen. Julkisuuteen meneminen voi esimerkiksi olla monipuoluehallitusten pelisääntöjen vastaista (Kriesi 2004, 203).

Kuten instituutioiden säännöt yleensä, myös julkisuussäännöt saattavat olla roolikohtaisia. Esimerkiksi saksalaisessa tutkimuksessa havaittiin, että valmisteluryhmien asiantuntijajäsenten ei toivottu kommentoivan keskeneräisiä asioita julkisuudessa. Poliitikoille julkinen kommentointi puolestaan sallittiin. (Spörer-Wagner \& Marcinkowski 2010, 20.)

Esa Reunanen ja kumppanit esittävät laajan tutkimuksensa pohjalta, että Suomen poliittisessa kulttuurissa vallitsisi jonkinlainen yhteisymmärrys "julkisuuspelin säännöistä" (Reunanen ym. 2010, 304). Reunanen ja kumppanit eivät kuitenkaan erittele, mitä nämä säännöt ovat. He eivät myöskään avaa, mihin käsitys sääntöjä koskevasta yhteisymmärryksestä varsinaisesti perustuu.

Aiemmassa tutkimuksessa on siis tehty lähinnä yksittäisiä huomioita ja oletuksia julkisuussäännöistä ja niiden vaikutuksesta päättäjien toimintaan. Aiemman tutkimuksen perusteella ei voi siten sanoa varmasti, onko todella olemassa vakiintuneita eli päättäjien itsestään selvänä pitämiä ja laajasti jakamia julkisuussääntöjä. Myöskään kysymystä siitä, missä määrin mahdolliset julkisuussäännöt todella selittävät päättäjien toimintaa, ei varsinaisesti ole tutkittu empiirisesti. Minkään tietyn instituution julkisuussääntöjä ei ole niin ikään tutkittu systemaattisesti.

Tässä artikkelissa tutkimme, millaisia julkisuussääntöjä kolmikantaisissa työryhmissä mahdollisesti on, miten vakiintuneita ne ovat ja millä tavoin ne vaikuttavat mediajulkisuudessa toimimiseen ja sitä kautta valmistelun läpinäkyvyyteen. Kolmikantainen valmistelu on hyvä esimerkki-instituutio julkisuussääntöjen tutkimiseksi ainakin kahdesta syystä. Ensinnäkin, kolmikantaisissa työryhmissä on usein kyse vastakkaisia ja vahvoja intressejä edustavien ryhmien välisestä neuvottelusta. Aiemmassa tutkimuksessa on havaittu, että mediajulkisuus on erityisen riskialtis paikka juuri tämän tyyppisissä neuvotteluinstituutioissa (Kunelius ym. 2010, 427, 431-436; Spörer-Wagner \& Marcinkowksi 2010). Koska julkinen keskustelu saattaa vaikeuttaa kompromissien tekemistä, on väitetty, että neuvotteluryhmien jäsenet joutuvat harkitsemaan tarkoin, miten he mediajulkisuudessa toimivat (esim. Spörer-Wagner \& Marcinkowksi 2010). Siksi on todennäköistä, että ainakin kolmikantaisen valmistelun kaltaisiin neuvotteluinstituutioihin on muodostunut sääntöjä, jotka säätelevät mediajulkisuudessa toimimista ja siten auttavat valmistelijoita hallitsemaan julkisuutta ja 
siihen liittyviä riskejä. Toiseksi, koska mukana on monentyyppisiä toimijoita (esimerkiksi virkamiehiä sekä järjestöjen edustajia), mahdolliset roolikohtaiset julkisuussäännöt tulevat todennäköisesti hyvin esille.

\section{Aineisto ja menetelmä}

Ensisijaisena aineistona käytämme 22 teemahaastattelua. ${ }^{9}$ Haastatellut olivat pääosin virkamiehiä, järjestöjen edustajia (erityisesti työmarkkinajärjestöistä) ja poliittisia toimijoita (poliittiset valtiosihteerit yms.). Haastateltuja oli yhteensä 17, ja heistä 13 oli Sata-komitean jäseniä ${ }^{\circ}$. Neljällä muulla henkilöllä on paljon kokemusta kolmikantaisesta valmistelusta, mutta he eivät olleet mukana Sata-komiteassa. Koska samat henkilöt ovat usein mukana komiteasta toiseen, potentiaalisten haastateltavien määrä on suhteellisen pieni (ks. esim. Tiitinen 2007). Tästä syystä haastateltuja on mielestämme myös riittävästi, jotta voidaan varovaisesti yleistää, että 2000-luvulla kolmikantaisessa työryhmämuotoisessa valmistelussa on havaitsemiamme julkisuussääntöjä.

Ensimmäisellä haastattelukierroksella syksyllä 2011 haastattelimme yhdeksää Satakomitean jäsentä. ${ }^{11}$ Haastattelut käsittelivät komitean päätöksentekoa, sosiaalipolitiikan ajattelumalleja ja mediajulkisuutta. Myös toisella kierroksella marraskuusta 2012 maaliskuuhun 2013 haastattelimme yhdeksää Sata-komitean jäsentä. Lisäksi haastattelimme neljää muuta henkilöä, joilla on paljon kokemusta kolmikantaisesta valmistelusta. ${ }^{12}$ Toisen kierroksen haastattelut keskittyivät lähes yksinomaan mediajulkisuudessa toimimiseen. Haastatteluja voi kuvata osittain strukturoiduiksi teemahaastatteluiksi. Kysymyksiä oli mietitty valmiiksi, mutta eri haastatteluissa käytetyt kysymykset eivät olleet keskenään täysin identtisiä. Kysymyksiä myös improvisoitiin vastausten perusteella haastattelujen aikana. Mediajulkisuudessa toimimiseen liittyvien alateemojen määrä vaihteli jonkin verran, eli kaikkia samoja asioita ei otettu esille kaikissa haastatteluissa. Ensimmäisellä haastattelukierroksella julkisuuteen liittyviä kysymyksiä oli usein selvästi vähemmän kuin toisella kierroksella.

Aineistona on myös Sata-komitean puheenjohtaja Markku Lehdon toimittajille järjestetyissä tausta- ja tiedotustilaisuuksissa näyttämät viisi Powerpoint-esitystä. Lisäksi aineistona ovat Sata-komiteaa käsittelevät artikkelit Helsingin Sanomista (HS) ${ }^{13}$ vuosilta 2007-2009 sekä Aamulehdestä (AL) ${ }^{14}$ ja Keskisuomalaisesta (KSML) vuosilta 20072008'5. Kävimme läpi myös Yleisradion internetsivuilla julkaistuja uutisia.

Haastatteluissa kysyimme muun muassa, millä tavoin haastateltavat itse toimivat ja miten komiteoiden jäsenet haastateltavien mielestä yleensä toimivat mediajulkisuudessa Sata-komitean ${ }^{16}$ ja vastaavien valmisteluryhmien aikana. Tiedustelimme esimerkiksi, millaisia keskusteluja haastateltavat kävivät toimittajien kanssa. Saadaksemme tietoa mediajulkisuudessa toimimisen taustalla olevista tekijöistä kuten mahdollisista julkisuussäännöistä, pyysimme usein haastateltavia reflektoimaan ja selittämään omaa ja muiden toimintaa mediajulkisuudessa. Tämän teimme monesti Sata-komiteaa koskevien esimerkkien avulla. Näytimme haastateltaville muun muassa heidän omiaan tai muiden komitean jäsenten ja ministerien ulostuloja mediassa. Sen jälkeen pyysimme 
haastateltavia kommentoimaan niitä. Kysyimme esimerkiksi, miksi haastateltava antoi jonkin kommentin toimittajalle. Konkreettisten esimerkkien avulla saimme tarkan käsityksen julkisuussääntöjen sisällöstä: haastatellut kuvailivat usein, millaisesta tilanteesta ja toiminnasta esimerkkitapauksissa oli kysymys ja miksi juuri sellaisessa tilanteessa saa tai kannattaa toimia tietyllä tavalla mediajulkisuudessa. Haastateltavan omien näkemysten ohella kysyimme välillä myös, miten haastateltava olettaa muiden komiteoiden jäsenten suhtautuvan erilaisiin tapoihin toimia julkisuudessa.

Edellä mainittujen kysymysten avulla saimme tietoa myös siitä, miten paheksuttavana tai hyväksyttävänä haastateltavat itse pitivät tai olettivat muiden komitean jäsenten pitävän tietynlaista julkista toimintaa. Hyväksyntä ja paheksunta kertovat säännöistä: mitä pidetään sallittuna ja mitä ei. ${ }^{17}$

Kysyimme usein myös suoraan, tehtiinkö Sata-komiteassa julkisuudessa toimimiseen liittyviä sopimuksia tai sääntöjä, ja miten niistä päätettiin. Lisäksi kysyimme, millaisia sääntöjä ja sopimuksia vastaavissa työryhmissä yleensä on. Rooliodotuksista saimme edellisten kysymysten lisäksi tietoa myös kysymällä, millaisia odotuksia haastateltavilla oli eri rooleissa toimivien julkisesta toiminnasta. Millä tavoin esimerkiksi virkamiesten tulee käyttäytyä mediajulkisuudessa?

Muodostimme käsityksemme julkisuussääntöjen sisällöstä siis monentyyppisten havaintojen perusteella. Päättelimme sääntöjen sisällön analysoimalla a) haastateltavien omia eksplisiittisiä käsityksiä sääntöjen ja rooliodotusten sisällöstä, b) heidän selityksiään omalle toiminnalleen julkisuudessa, c) haastateltavien esittämää hyväksyntää tai paheksuntaa muiden Sata-komitean jäsenten julkisuudessa toimimista kohtaan sekä d) haastateltavien käsityksiä siitä, millaista toimintaa muut komiteoiden jäsenet pitävät hyväksyttävänä tai paheksuttavana.

Saadaksemme selville, miten vakiintuneita säännöt ovat, tarkastelimme ensinnäkin sitä, miten yhdenmukaisia haastateltavien käsitykset olivat: miten monella haastateltavalla on samanlaisia käsityksiä siitä, millainen julkisuudessa toimiminen on sallittua ja millainen ei. Luotimme myös haastateltavien omaan muistiin ja katsoimme, miten yleisinä, "normaaleina" tai "itsestään selvinä" he pitivät tiettyjä toimintatapoja ja sääntöjä. Lisäksi tarkastelimme sitä, missä määrin ja millä tavoin mediajulkisuuteen liittyvistä eri toimintatavoista ja säännöistä keskusteltiin komiteassa. Tämä kertoo sääntöjen vakiintumisen asteesta. Vahvasti institutionalisoituneista säännöistä ei tarvitse juuri keskustella, koska kaikki toimijat pitävät niitä itsestään selvinä (Colyvas \& Powell 2006, 309).

Käytännössä aineiston analysoinnissa oli kaksi vaihetta. Ensin luokittelimme litteroidut haastattelut teemoittain. Teemoja olivat julkisuuteen suhtautumisen eri osa-alueet, kuten kysymys komitean asiakirjojen ja keskustelujen luottamuksellisuudesta, vuodot sekä komitean käsittelemien aiheiden julkinen kommentointi omalla nimellä. Teemoja olivat myös roolit. Luokittelimme omiin kategorioihinsa esimerkiksi virkamiesten, järjestöjen edustajien ja ministerien toimintaa julkisuudessa käsittelevät haastattelulainaukset. Toisessa vaiheessa luokittelimme yksityiskohtaisemmin kunkin teeman sisällä ne havainnot, joista päättelimme julkisuussääntöjen sisällön ja sen, miten vakiintuneita ne ovat. Esimerkiksi keskustelujen ja asiakirjojen luottamuksellisuuden kohdalla luokittelimme omiin kategorioihin haastattelupätkät, joista tuli ilmi a) mitä haastateltu piti 
luottamuksellisena, b) miten itsestään selvänä haastateltu asiaa piti ja c) millä tavoin asiasta sovittiin tai keskusteltiin Sata-komiteassa.

Sata-komitean toiminnan läpinäkyvyyttä tutkimme sanomalehtiaineiston ja toimittajille järjestettyjen taustatilaisuuksien Powerpoint-esitysten sekä haastattelujen avulla. Kiinnitimme erityisesti huomiota siihen, miten komitean työn sisältöä ja tavoitteita kuvattiin näissä aineistoissa, sekä vertasimme näitä kuvauksia komitean työn tosiasialliseen sisältöön ja lopputuloksiin.

\section{Keskustelujen ja asiakirjojen luottamuksellisuus}

Sata-komiteassa oli sääntö, että komitean kokouksissa käydyt keskustelut ja komitean tuottamat keskeneräiset asiakirjat olivat luottamuksellisia eli komitean jäsenten ei tulisi puhua niiden sisällöstä julkisuudessa. Tästä tehtiin komiteassa suullinen sopimus, ja tämä myös kirjattiin komitean viestintäsuunnitelmaan (STM 2008, 2, 4).

Sääntö keskustelujen ja keskeneräisten asiakirjojen luottamuksellisuudesta on vakiintunut. Tästä kertoo ensinnäkin se, että kaikki haastatellut olivat asiasta samaa mieltä. Lisäksi monen haastatellun mukaan asiasta sovittiin komiteassa vain hyvin lyhyen keskustelun perusteella, ja osa muisteli, että tässä keskustelussa ei tullut esille erimielisyyttä:

Minä en muista, että kuinka paljon siitä käytiin keskustelua, koska se on oikeastaan ollut kaikille itsestään selvä, että, ja kuuluu siihen komitean työrauhaan, että siitä se lähti. ${ }^{18}$ (Työmarkkinajärjestön edustaja Sata-komiteassa.)

Säännön vakiintuneisuudesta kertoo myös se, että haastatellut kuvasivat keskustelujen ja keskeneräisten asiakirjojen luottamuksellisuutta "itsestään selväksi", "normaaliksi" tai "yleiseksi tavaksi", jota noudatetaan kaikissa vastaavissa työryhmissä (ks. myös Pulkkinen 2011, 74). Sääntöä pitivät itsestään selvänä myös ne haastateltavat, jotka joko eivät olleet läsnä silloin, kun asioiden luottamuksellisuudesta sovittiin, tai eivät haastattelutilanteessa muistaneet tätä sopimusta. Kysyttäessä oliko komitean jäseniä kielletty puhumasta komiteassa käsiteltävistä asioista mediassa, yksi heistä vastasi seuraavasti:

Ei sitä varmaan sen tason ihmisille, jotka siellä komiteassa istuu, niin ei sitä tarvitse edes erikseen varmana linjata, kyllä se on lähtökohtaisesti niin kuin se on. Että siellä on kolmikantaneuvottelijat ja nämä ne on. Tai että se on suunnilleen sama, että tehtiinkö siellä linjaus, että lattialle ei saa pissata. - - Että eiköhän se lähtökohtaisesti.

\section{Tiedotustoiminta}

Vaikka asiakirjat ja keskustelut olivat luottamuksellisia, Sata-komiteassa sovittiin, että puheenjohtaja kertoo tai tiedottaa komitean työstä tarvittaessa medialle (STM 2008, 2). 
Haastatellut pitivät puheenjohtajavetoista tiedottamista vakiintuneena käytäntönä. Yhden haastatellun mukaan käytäntö oli olemassa jo 1970-luvulla.

Toimittajille järjestettiin tausta- ja tiedotustilaisuuksia Sata-komitean työn kaikissa vaiheissa (esim. 29.11.2007, 19.8.2008 ja 30.4.2009). Niissä komitean puheenjohtaja Markku Lehto ja sosiaali- ja terveysministeri Liisa Hyssälä (kesk.) kertoivat toimittajille työn tavoitteista ja etenemisestä. Lehto kuvaili tilaisuuksissa yleisellä tasolla, mitä asioita komitea oli käsitellyt, millaisia haasteita sosiaaliturvan uudistamiseen liittyi ja millaisiin ratkaisuihin komitea saattaisi päätyä. Asioiden luottamuksellisuutta koskevan julkisuussäännön mukaisesti hän ei kuitenkaan kertonut, mitä komitean jäsenet olivat sanoneet komitean kokouksissa. (Haastattelut, Markku Lehdon Powerpoint-esitykset 5.2.2008 ja 19.8.2008.) Näin eri toimijoiden konkreettiset tavoitteet eivät tulleet tiedotuksessa selkeästi esille.

Komitean työstä julkisuuteen annettu tieto jäi tämän käytännön vuoksi niin yleiselle tasolle, että se ei särkenyt sanomalehdissä muodostunutta kuvaa Sata-komiteasta ryhmänä, joka pyrkii erityisesti vähentämään köyhyyttä ja siten korjaamaan sosiaalisia epäoikeudenmukaisuuksia ja tuloerojen kasvua (esim. KSML 24.8.2007; KSML 13.1.2008; HS 2.3.2008; AL 8.5.2008; HS 8.5.2008). Helsingin Sanomien pääkirjoituksen mukaan " - - sosiaalisen epäoikeudenmukaisuuden ilmentymät ovat suurimmaksi osaksi juuri niitä, joiden kimpussa sosiaaliturvan kokonaisuudistusta rakentava Satakomitea työskentelee" (HS 2.3.2008). Uutisissa myös toistettiin poliitikkojen lupauksia sosiaaliturvan parantamisesta. Helsingin Sanomat kirjoitti, että "hallitus lupaa kaikille 'kohtuullisen tasoisen' sosiaaliturvan" (HS 8.5.2008). Aamulehti muotoili hallituksen tiedotustilaisuuden pohjalta, että komitean työssä "etusijalle pääsevät kuitenkin asiat, joissa näkyy selvä epäoikeudenmukaisuus" (AL 8.5.2008). ${ }^{19}$

\section{Vuodot}

Moni haastateltu totesi, että luottamuksellisuuden rikkominen on työryhmissä ja komiteoissa hyvin tyypillistä. Se tapahtuu yleensä siten, että joku vuotaa luottamuksellisia tietoja nimettömästi julkisuuteen. Haastateltavat kuvasivat vuotoja eräänlaiseksi maan tavaksi kolmikantaisessa valmistelussa.

Haastateltavilla oli keskenään hyvin samanlaisia nyrkkisääntöjä, joiden avulla he päättelivät, kuka tai mikä taho on tietyn vuodon tehnyt. Tyypillisesti vuotajan oletetaan olevan komiteassa vähemmistöön jäänyt toimija, joka haluaa vuotojen avulla laittaa "pelin sekaisin" ja sabotoida komitean lopputuloksen. ${ }^{20}$ Esimerkiksi kysyttäessä, millaisissa tilanteissa kannattaa vuotaa, eräs haastateltu vastasi näin:

Esimerkiksi silloin, jos näyttää siltä, että se komitean lopputulos on itsensä kannalta sellainen, jota ei mitenkään voi hyväksyä. Sitähän voi koettaa torpedoida sillä, että se asia menee julkisesti sekaisin. Ja sillä, että sen ehdotuksen huonot puolet tulee julkisuuteen ennen sitä ehdotusta. (Työmarkkinajärjestön edustaja, ei mukana Sata-komiteassa.) 
Nyrkkisääntöjen vuoksi komiteoiden jäsenet osaavat odottaa vuotoja erityisesti silloin, kun joistain asioista ollaan vahvasti eri mieltä. Tällöin vuotojen uhka saattaa toimia itseään toteuttavana ennusteena. Ainakin yhden haastateltavan mukaan voi nimittäin syntyä kilpajuoksu siitä, kuka saa näkökulmansa ensimmäisenä mediajulkisuuteen:

Jos alkaakin vaikuttaa siltä, että se on menossa kivikkoiseksi, karille, ja joka tapauksessa siihen alkaa tulla jännitteet, niin silloin kyllä se vaan jossain kohtaa menee niin, että toimittajat alkavat tietää, ja silloin yleensä se, joka latasee sen ekana julkisuuteen, on jollakin tavalla ehkä yhden askeleen edellä - - (Työmarkkinajärjestön edustaja Sata-komiteassa.)

Myös Sata-komiteassa vuodettiin asioita julkisuuteen useaan kertaan (ks. myös Soininvaara 2010, 275-276). Vuotojen kautta mediajulkisuudessa tuli marraskuusta 2008 lähtien lopulta aiempaa konkreettisemmin näkyviin, minkä tyyppisiä päätösvaihtoehtoja komiteassa pohdittiin sosiaaliturvan kannustavuuden ja työvoiman tarjonnan lisäämiseksi. Julkisuuteen vuodettiin esimerkiksi komiteassa esillä ollut malli, jonka palkansaajat tulkitsivat ansiosidonnaisen työttömyysturvan heikennykseksi. Heidän mielestään se olisi lyhentänyt ansiosidonnaisen työttömyysturvan maksimikestoa. (HS 6.11.2008.)

Vuodot osoittavat, että julkisuussääntöjä ei aina noudateta. Kulloinenkin poliittinen tilanne näyttäisi selittävän luottamuksellisuutta koskevaa julkisuussääntöä vahvemmin sitä, milloin valmistelu nousee julkiseen keskusteluun. Sääntöä yleensä noudatetaan niin kauan kuin valmistelu etenee ilman suurempia ristiriitoja, koska vuodoista ei ole tällöin hyötyä. Niistä on tällöin pikemminkin haittaa, sillä ne heikentävät komitean jäsenten välistä luottamusta. Vuotaminen voi kuitenkin olla eri osapuolille hyödyllinen taktiikka erityisesti silloin, kun komiteassa on vahvoja erimielisyyksiä.

\section{Omista tavoitteista puhuminen mediajulkisuudessa}

Sääntö komiteassa käytyjen keskustelujen ja keskeneräisten asiakirjojen luottamuksellisuudesta ei kuitenkaan merkitse sitä, että komitean jäsenet eivät puhuisi mediajulkisuudessa mitään. Sääntönä on ensinnäkin, että valmistelussa esillä olevista kysymyksistä ja niiden taustoista saa kertoa toimittajille yleisellä tasolla:

Minä pidin tietysti huolen, että en minä lähtenyt kertomaan, että onko komiteassa joku ratkaisupaperi olemassa vai eikö ole, enkä lähtenyt ennustamaan, että (mihin) komitea siltä osin tulee päätymään. - - Mutta kyllä minä näistä substansseista puhuin ihan vapaasti (toimittajille). (Sata-komitean jäsen.)

Kaikki haastatellut etujärjestöjen edustajat ja poliittiset toimijat olivat myös sitä mieltä, että järjestöjä tai puolueita edustavat komitean jäsenet saivat tuoda Sata- 
komitean aikana julkisuudessa esille tavoitteitaan sosiaaliturvan uudistamisessa (myös Pulkkinen 2011, 78). Monen mielestä tämä on yleinen sääntö kaikissa komiteoissa ja valmisteluryhmissä. Melkein kaikki etujärjestöjen edustajat ja poliittiset toimijat pitivät tätä sääntöä itsestään selvänä:

No tietysti nämä tavoitteet, nehän on aina ollut lähtökohtaisesti julkisia. Ettei me olla koskaan omia tavoitteitamme yritettykään piilottaa, ja saman tekee tietysti kaikki muutkin keskeiset komiteatahot. Sillä lailla tietysti julkisuuden kautta pyritään vaikuttamaan, että sitä omaa linjaa markkinoidaan myös sitten julkisuuteen. (Työmarkkinajärjestön edustaja Sata-komiteassa.)

Sata-komitean jäsenet esittelivät tavoitteitaan mediajulkisuudessa jonkin verran. Esimerkiksi EK:ta edustanut Lasse Laatunen avasi Kansan Uutisissa (17.7.2008) laajasti EK:n tavoitteita. Laatunen toi jutussa muun muassa esille, että EK tavoitteli työnantajien KELA-maksujen poistoa ja osa-aikaeläkkeelle pääsemisen ikärajan nostamista. Tämäntyyppisten ulostulojen kautta mediajulkisuudessa tuli näkyviin - tosin vasta lähes komitean työn puolivälissä - millaisia konkreettisia tavoitteita komitean jäsenillä oli esimerkiksi kannustavuuden ja työvoiman tarjonnan lisäämiseksi. Jotkut järjestöt, kuten SAK ja STTK, myös pitivät komitean työn aikana toimittajille taustatilaisuuksia, joissa ne muun muassa esittelivät tavoitteitaan sosiaaliturvan uudistamisessa (ks. myös Pulkkinen 2011, 74).

Siihen, milloin ja millaisissa kysymyksissä komiteajäsenet tuovat tavoitteitaan tai kantojaan mediajulkisuuteen, liittyy kuitenkin paljon taktista harkintaa. Komitean jäsenet harkitsevat julkisia kannanottoja tarkkaan ensinnäkin siksi, että niistä saattaa olla heille itselleen haittaa. Osa haastateltavista sanoi, että esitellessään tavoitteitaan mediajulkisuudessa komitean jäsenten koetaan "naulaavan" kantansa kiinni. Heidän mukaansa julkinen keskustelu siten "betonoi" neuvotteluasetelmia (ks. myös Kantola 2002, 287). Muutaman haastatellun mielestä julkisuuteen ei myöskään kannata mennä muille osapuolille kipeissä tai aroissa kysymyksissä. Järjestöjen tai puolueiden vanhoista ja yleisesti tiedossa olevista tavoitteista voi joidenkin haastateltujen mukaan kuitenkin yleensä puhua julkisuudessa ilman, että se haittaisi merkittävästi komitean työtä. Lisäksi jo mediajulkisuuteen tavalla tai toisella noussutta asiaa voi haastateltujen mielestä yleensä kommentoida.

Kannanottoihin liittyvä taktinen harkinta kertoo siitä, että sääntö kannanottojen hyväksyttävyydestä ei selitä kovin voimakkaasti sitä, missä määrin ja milloin komitean jäsenet tuovat tavoitteitaan esille mediajulkisuudessa. Koska sääntö sallii sekä julkiseen keskusteluun osallistumisen että mediajulkisuudesta vetäytymisen, tilanne- ja asiakohtainen harkinta selittää julkisia kannanottoja sääntöä voimakkaammin.

Sääntö julkisten kannanottojen hyväksyttävyydestä ei kuitenkaan ole täysin vakiintunut. Tästä kertoo ensinnäkin se, että varsinkin osa virkamiehistä näyttäisi suhtautuvan tavoitteiden julkiseen esittelemiseen keskimäärin kielteisemmin kuin moni työmarkkinajärjestöjen edustaja ja poliitikko. Erityisesti monen haastatellun virkamiehen mielestä tavoitteiden esitteleminen mediajulkisuudessa haittaa huomattavasti komi- 
teoiden työskentelyä, eivätkä virkamiehet yleensä suhtautuneet julkisiin kannanottoihin muutenkaan kovin suopeasti. Esimerkiksi yksi virkamies arvioi työmarkkinajärjestöjen julkisia kannanottoja seuraavasti:

- - Varmaan tähän demokratiaan kuuluisi se, että jokainen voi omia näkemyksiä esitellä, siinä mielessä ihan jees. Mutta että tietysti jokainen ymmärtää, mitä tuosta seuraa, koska sitten toiset kokevat että "ahaa, ne ovat tuota mieltä", ja sitten ne lyövät ne omat paalunsa. - - Että ei se sillä lailla työtä helpota. (Sata-komitean virkamies.)

Näkemyserot tulivat konkreettisesti esille, kun muutamaa haastateltavaa pyydettiin kommentoimaan lehtijuttua, jossa eräs Sata-komitean jäsen toi esille organisaationsa tavoitteita komitean työssä. Työmarkkinajärjestön edustajan mielestä kyseinen ulostulo ei ollut sopimaton:

Kyllä minä tulkitsen tämän (komitean jäsenen X) kannanoton, vähän muistelenkin että jotakin tällaista oli, ikään kuin (organisaation X) tavoitteiden toistamiseksi. Että se että toistaa - - tavoitteita, niin se on vähän eri asia kuin (että) ryhtyy kommentoimaan sitä mitä siellä tapahtuu ja kuka on esittänyt tyhmiä mielipiteitä ja kuka ei. (Työmarkkinajärjestön edustaja Sata-komiteassa.)

Sen sijaan haastateltu virkamies tuomitsi saman ulostulon jyrkästi:

Ei pidetty sopivana tietenkään, että sehän oli aivan mieletön puheenjohtajalle. - - Se jos olisi sovittu sillain, että testattaisiin esimerkiksi tällaista yhteiskunnallista keskustelua, niin sehän olisi ihan hyvä tapa, mutta näistä ei sovittu, nämähän pöllähti vaan sitten aina eri vaiheissa sitten esille. Siinä samalla saa pienen sulan hattuunsa jotkut. (Satakomitean virkamies.)

Säännön vakiintumattomuudesta kertoo todennäköisesti myös se, että muutaman haastateltavan mukaan komiteassa keskusteltiin monta kertaa siitä, onko kannan ottaminen julkisuudessa sopivaa. Yksi haastateltu esimerkiksi muisteli, että eräs työmarkkinajärjestön edustaja oli puolustanut seuraavalla tavalla komitean jäsenten oikeutta tuoda julkisuudessa esille tavoitteitaan:

Muistaakseni - - (työmarkkinajärjestö X) oli sanoneet jotakin niin, silloin (työmarkkinajärjestön edustaja $X$ ) sanoi ihan hyvin, että eihän tämä voi olla näin, että kahteen ja puoleen vuoteen (työmarkkinajärjestö X) ei sano mitään sosiaaliturvasta, että totta kai heillä pitää olla mahdollisuus esittää kehittämisehdotuksia, ja jos joku esittää heidän mielestään pöljän esityksen, niin kertoa että heidän mielestään tämä ei ole perusteltu esitys, ja se, että samaa asiaa puhutaan komiteassa, ei tarkoita, että siellä (julkisuudessa) puhutaan komitean sisäisiä asioita. Ja tämä oli semmoinen rajanvetokeskustelu, jota ei minun mielestä kyllä sen jälkeen mitenkään isommin käyty. (Työmarkkinajärjestön edustaja Sata-komiteassa.) 
Virkamiehet kokivat erityisen vahvasti, että nimenomaan heidän itsensä tulee käyttäytyä julkisuudessa pidättyväisesti keskeneräisen työn aikana (ks. myös Pulkkinen $2011,86)$. Virkamiehet sanoivat kertovansa toimittajille yleisellä tasolla liikkuvaa taustatietoa mutta välttävänsä erityisesti kannan ottamista. Virkamiesten mielestä heidän tulee käyttäytyä julkisuudessa objektiivisesti ja puolueettomasti, eivätkä he saa ylittää valtuuksiaan esimerkiksi menemällä poliitikkojen tontille (vrt. Kunelius ym. 2010, 318):

- - Täytyy käyttäytyä objektiivisesti, mutta että kertoa se totuus minkä tietää, että ei voi lähtee silleen pohtimaan jotakin sellaista mikä on poliittisen päätöksenteon tai jonkun muun elimen päätettävissä (Sata-komitean virkamies).

Virkamiehet viittasivat usein siihen, että sopimukset, ja yhden virkamiehen mielestä myös laki, ohjaavat heidän toimintaansa julkisuudessa:

- - Virkamiehillä, niin meillähän on sillain jo virkamieslaissakin, ja rikoslaissa se erityisesti on, että jos ei asemansa edellyttämällä tavalla käyttäydy, niin voi ilman perusteluja, vaikka tänä päivänä ilmoittaa, että et ole palveluksessa. Että se jarruttaa sen, että sen aseman mukaisesti täytyy käyttäytyä - - (Sata-komitean virkamies.)

Järjestöjen edustajien suhtautumisessa virkamiesten julkisiin kannanottoihin on eroja. Kahden työmarkkinajärjestöjen edustajan mielestä komiteoiden täysvaltaisina jäseninä toimivien virkamiesten julkisille kannanotoille ei ole estettä. Parin työmarkkinajärjestöjen edustajan mukaan virkamiesten pitäisi kuitenkin käyttäytyä pidättyväisesti ja puolueettomasti niin julkisuudessa kuin sen ulkopuolellakin. Kaikilla työmarkkinajärjestöjen edustajilla ei siis ole sellaista normatiivista rooliodotusta, että virkamiesten pitäisi olla julkisuudessa pidättyväisiä. Moni järjestöjen edustaja kuitenkin sanoi, että virkamiehet yleensä pitävät matalaa profiilia. Siten kyseessä näyttäisi olevan suhteellisen vahva rooliodotus.

Näyttää siltä, että sääntö julkisista kannanotoista ei koske samalla tavalla kaikissa rooleissa toimivia komiteoiden jäseniä. Järjestöjen ja puolueiden edustajille julkiset kannanotot sallitaan kernaammin kuin virkamiehille.

Virkamiesten suhtautuminen julkisuuteen muistuttaa Max Weberin esittämää byrokratian ideaalityyypiä. Siinä käyttäytyminen perustuu lakiin ja muihin selkeisiin sääntöihin, virkamiesten ja poliitikkojen roolit on selvästi erotettu toisistaan ja virkamiesten edellytetään käyttäytyvän objektiivisesti ja neutraalisti. (Weber 1970a, 1970b, 95; ks. myös Hallin \& Mancini 2004, 55-59; Sager \& Rosser 2009, 1139.) Ainakin sosiaalipolitiikassa virkamiesten rooli on kuitenkin jännitteinen, koska osan heistä koetaan olevan lojaaleja tietylle puolueelle. Politiikan tutkija Paul Sabatier (1998) on esimerkiksi esittänyt, ettei poliittisesti neutraaleja toimijoita ole, vaan kaikki relevantit toimijat kuuluvat johonkin valtaryhmittymään (Advocacy Coalition). Valtaryhmittymät koostuvat Sabatierin mukaan virkamiehistä, tutkijoista, poliitikoista, etujärjestöjen edustajista ja jopa toimittajista. Tämä eri toimijoiden välinen jännite näkyi myös Sata-komiteassa siinä parin haastatellun epäilyksessä, että kaikki komitean virkamie- 
het eivät toimineet mediajulkisuudessa neutraalisti vaan ajoivat julkisuudessa omia tai edustamansa puolueen tavoitteita esimerkiksi vuotojen avulla.

\section{Ministerien julkiset kannanotot}

Haastatteluissa tuli esille myös vahvoja rooliodotuksia siitä, miten ministerien tulisi käyttäytyä mediajulkisuudessa. Monen haastatellun mielestä ministerien ei tulisi ottaa julkisuudessa kantaa komiteoissa käsiteltäviin kysymyksiin niiden työn ollessa kesken. Muutama haastateltu piti tätä "vanhana pelisääntönä" tai "hyvänä tapana". Näin ajattelivat myös jotkut niistä työmarkkinajärjestöjen edustajista, jotka pitivät komitean jäsenten julkisia kannanottoja sopivina.

Haastateltu työmarkkinajärjestön edustaja selitti asiaa sillä, että ministereiden rooli on erilainen kuin muiden toimijoiden. Hänen mukaansa ministeri on valmistelun "toimeksiantaja", ja on ongelmallista, jos toimeksiantaja ryhtyy "työn keskellä antamaan julkisuuden kautta ohjeita, mitä pitää tehdä".

Ministerit kuitenkin usein toimivat tämän rooliodotuksen vastaisesti. Esimerkiksi muutama ministeri otti mediajulkisuudessa voimakkaasti kantaa Sata-komitean asioihin. Keskusta muun muassa ajoi julkisuudessa kansaneläkkeen tason nostamista pääministeri Matti Vanhasen johdolla (KSML 15.06.2008; HS 3.9.2008), ja kokoomuksen opetusministeri Sari Sarkomaa vastusti toimeentulotuen maksamisen siirtämistä Kelaan (HS 9.11.2008). Yhden virkamiehen mielestä ministerien julkinen kommentointi vaikeutti olennaisesti komitean työtä (ks. myös Saari 2011, 94):

Niin no tuo oli juuri se, mikä teki sen komitean työn hankalaksi. Että ministerit ja poliitikot rupesivat käymään julkisuudessa tätä keskustelua ennen kun mitään tehtiinkään, mikä ei millään tavalla helpottanut asiaa. (Sata-komitean virkamies.)

Kaikki eivät kuitenkaan pitäneet ministerien ulostuloja välttämättä häiritsevinä tai sopimattomina. Kahden haastatellun mielestä ratkaisevaa näyttäisi olevan se, mistä asioista ja millä tavoin ministerit puhuvat julkisuudessa. Heidän mielestään esimerkiksi puolueiden vakiintuneista tavoitteista tai vaalilupauksista puhumista pidetään sopivana. Koska kaikki eivät olleet asiasta samaa mieltä, näyttää siltä, että tämä sääntö ei ole täysin vakiintunut.

\section{Johtopäätökset}

Tutkimuksemme toi esille, että kolmikantaisissa valmisteluryhmissä on useita enemmän tai vähemmän vakiintuneita julkisuussääntöjä eli sääntöjä, jotka koskevat mediajulkisuudessa toimimista. Sääntönä on, että komiteoiden jäsenten ei tulisi antaa komiteassa käydyistä keskusteluista ja keskeneräisistä asiakirjoista tietoja julkisuuteen, mutta puheenjohtaja tiedottaa niistä tarvittaessa. Järjestöjen edustajat ja poliittiset 
toimijat noudattavat myös sääntöä, jonka mukaan komitean jäsenet voivat esitellä julkisuudessa omia tavoitteitaan. Osa säännöistä on roolikohtaisia. Virkamiehet kokevat, että heiltä odotetaan pidättyväistä ja puolueetonta käyttäytymistä julkisuudessa. Ministerien ei toivota ottavan julkisuudessa kantaa valmistelussa oleviin asioihin.

Kolmikantaisen valmistelun julkisuussäännöt näyttävät olevan ongelmallisia päätöksenteon läpinäkyvyyden kannalta. Sata-komitea jatkoi 199o-luvulla vakiintunutta suomalaisen sosiaalipolitiikan linjaa, jossa on korostunut elinkeinoelämän intressi pienentää työvoimakustannuksia. Elinkeinoelämä oli myös Sata-komiteassa vahva vallankäyttäjä. Komitean ensimmäisen vuoden aikana mediajulkisuudessa moni kuitenkin odotti, oletti tai lupasi, että komitea vähentäisi köyhyyttä merkittävästi ja korjaisi siten erityisesti sosiaalisia epäoikeudenmukaisuuksia sekä tuloerojen kasvua. Tällainen julkisuuskuva osoittaa, että komiteassa esillä olleet päätösvaihtoehdot ja sen jäsenten konkreettiset tavoitteet eivät olleet nousseet kattavasti julkiseen keskusteluun. Harhaanjohtavaa julkisuuskuvaa piti osaltaan yllä komitean virallinen tiedotustoiminta, jossa liikuttiin vakiintuneiden julkisuussääntöjen mukaisesti vain yleisellä tasolla. Komitean sisäisten keskustelujen ja keskeneräisten asiakirjojen luottamuksellisuuden vuoksi sen jäsenten konkreettisista tavoitteista ei tiedotettu julkisuuteen. Työvoiman tarjonnan lisäämisen tavoitteet eivät siksi hahmottuneet kaikille toimittajille poliittisina kysymyksinä. Työn tarjontaa on suomalaisessa sosiaalipolitiikassa yritetty lisätä 1990-luvun alusta asti leikkaamalla sosiaalietuuksia, kiristämällä niiden saantiehtoja ja alentamalla verotusta. Tuloerojen vähentämisen kanssa ristiriidassa olleita päätösvaihtoehtoja ja Sata-komitean jäsenten tavoitteita nousi julkiseen keskusteluun vasta vuotojen ja koordinoimattomien ulostulojen kautta.

Tutkimustulokset viittaavat siihen, että poliittisissa instituutioissa on vakiintuneita eli itsestään selvinä pidettyjä ja päättäjien laajasti jakamia julkisuussääntöjä. Jatkossa julkisuussäännöt kannattaa siis ottaa muiden tekijöiden, kuten median toimintatapojen, ohella huomioon poliittista viestintää selitettäessä. Esimerkiksi medioitumista (esim. Mazzoleni \& Schulz 1999) tutkittaessa voi olla hyvä pitää mielessä se mahdollisuus, että julkisuussäännöt saattavat pitää pintansa, vaikka median muutos kannustaisi päättäjiä muuttamaan toimintatapojaan (vrt. Brown 2011, 69). Tämä on kenties yksi syy siihen, miksi politiikan medioituminen ei välttämättä lisää päätöksenteon läpinäkyvyyttä (Herkman 2009, 85). Toisaalta on mahdollista sekin, että päättäjät muuttavat julkisuussääntöjä medioitumisen myötä. Tämä mahdollinen sääntöjen muutos voisi olla hyvä jatkotutkimuksen aihe.

Vaikka julkisuussäännöt vaikuttavat julkisuudessa toimimiseen, niiden selitysvoimaa ei pidä liioitella. Sääntöjä ensinnäkin rikotaan tarvittaessa, kuten vuodot osoittavat. Lisäksi jotkut säännöt ovat luonteeltaan pikemminkin sallivia kuin rajoittavia, jolloin säännöt eivät määrää sitä, millä tavalla kulloinkin toimitaan. Poliittiseen tilanteeseen ja valmisteltavien asioiden sisältöön perustuva taktinen harkinta näyttää siis usein selittävän mediajulkisuudessa toimimista vahvemmin kuin julkisuussäännöt sinänsä. Toisaalta säännöillä on merkitystä myös silloin, kun niitä rikotaan. Ne vaikuttavat siihen, miten julkisuuteen liittyviä tekoja tulkitaan. Esimerkiksi kolmikantai- 
sessa valmistelussa luottamuksellisuuden rikkominen on usein vahva signaali siitä, että jokin osapuoli on erittäin tyytymätön siihen, mihin suuntaan valmistelu on menossa.

Ainakin kolmikantaisen valmistelun kohdalla julkisuussääntöjen selitysvoimaa vähentää myös se, että kaikki julkisuusäännöt eivät ole täysin vakiintuneita. Tutkimuksemme viittaa siihen, että suomalaisten päättäjien keskuudessa ei välttämättä vallitse täysi yhteisymmärrys julkisuussäännöistä (vrt. Reunanen ym. 2010, 304). Joidenkin sääntöjen vakiintumattomuus saattaa johtua siitä, että päättäjät tulkitsevat ja venyttävät sääntöjen sisältöä omista intresseistään käsin. Esimerkiksi työmarkkinajärjestöjen edustajat varaavat itselleen mahdollisuuden osallistua julkiseen keskusteluun tarvittaessa, mutta ministerien julkisia kannanottoja he eivät yleensä mielellään sallisi. Suhtautumistapojen erot voivat liittyä osittain siihen, että kaikki toimijat eivät tarvitse mediajulkisuutta yhtä paljon (vrt. Kunelius \& Reunanen 2012). Esimerkiksi virkamiehet, jotka eivät usein itse tarvitse mediajulkisuutta kovin paljon, näyttäisivät usein ajattelevan, että kaikissa rooleissa toimivien valmistelijoiden ja päättäjien olisi hyvä olla ottamatta julkisuudessa kantaa keskeneräisiin asioihin.

\section{Rahoitus}

Tutkimusta ovat rahoittaneet Koneen Säätiö ja Suomen Akatemia.

\section{Viitteet}

1 Työlainsäädännön valmistelua voi tosin kutsua myös nelikantaiseksi silloin, kun Suomen Yrittäjät osallistuu siihen (Tiitinen 2007, 248). Valmistelua on kutsuttu myös kaksikantaiseksi silloin, kun työmarkkinajärjestöt käytännössä sopivat asioista keskenään.

2 Vaikka Sata-komitea esitti merkittäviä uudistuksia, odotus kokonaisuudistuksesta osoittautui ylimitoitetuksi. Suomalainen sosiaaliturva on syntynyt eri intressiryhmien sopimusten myötä, ja vallitsevan käytännön mukaisesti sosiaaliturvalainsäädäntöä ei muuteta ilman näiden ryhmien hyväksyntää. Siksi muutokset ovat välttämättä asteittaisia.

3 Lisäksi komiteaan kuului muiden etu- ja kansalaisjärjestöjen sekä tutkimuslaitosten edustajia. Komiteassa ja sen alajaostoissa oli yhteensä noin 60 jäsentä.

$4 \quad$ KELA-maksun poisto ei ollut varsinaisesti Sata-komitean esitys, mutta se kytkettiin komitean esityksiin niin sanotussa sosiaalitupossa tammikuussa 2009.

5 Osa haastattelemistamme komitean jäsenistä selitti komitean tavoitteiden ja lopputuloksen välistä ristiriitaa sillä, että taloustaantuma muutti tilannetta ratkaisevasti vuodesta 2008 lähtien. Komiteassa yleinen tulkinta oli, että taantumassa sosiaaliturvamenojen kasvu ei olisi ollut järkevää. Rahaa kuitenkin riitti työnantajien KELA-maksun poistamiseen, jota perusteltiin elvytyksellä.

6 Sääntöjen immanentti normatiivisuus tarkoittaa sitä, että normatiivisia kysymyksiä tulee esille silloin, kun tietty sääntö kyseenalaistetaan tai siitä keskustellaan (Hodgson 2006, 3).

7 Tässä olemme eri mieltä Hodgsonin $(2006,3)$ kanssa, jonka mukaan instituutioista voi saada tietoa vain havainnoimalla käyttäytymistä.

8 Ks. myös Political Communication 2/2006 ja Journalism Studies 1/2011.

9 Lisäksi kuusi haasteltavaa vastasi haastattelujen jälkeen lisäkysymyksiin puhelimitse tai sähköpostitse.

10 Viittä Sata-komitean jäsentä haastattelimme kaksi kertaa.

$11 \quad$ Kaikissa haastatteluissa oli paikalla vain yksi haastateltava ja yksi haastattelija.

12 Näistä haastateltavista kolmella oli kokemusta erityisesti työlainsäädännöstä ja yhdellä laajemmin erityyppisistä kolmikantaisesti valmisteltavista asioista. 
13 HS:n artikkelit keräsi Stella Mattsson, jota kiitämme huolellisesta työstä.

14 Aamulehden artikkelit on kerätty Suomen Media-arkistosta, jota kiitämme yhteistyöstä.

15 AL:stä ja KSML:sta kerättiin jutut vain vuoden 2008 loppuun asti, koska aineiston avulla oli tarkoitus lähinnä testata sitä, pätikö Helsingin Sanomien artikkelien perusteella tekemämme havainto komitean harhaanjohtavasta julkisuuskuvasta muissakin lehdissä.

16 Sata-komiteasta ei kuitenkaan kysytty niiden henkilöiden haastatteluissa, jotka eivät olleet Satakomiteassa.

17 Koska haastateltavilla oli erilaisia kantoja sosiaaliturvaan liittyviin kysymyksiin, pyrimme esimerkiksi julkisten kannanottojen kohdalla erottamaan toisistaan kannanottojen asiasisältöä ja toisaalta kannan ottamista sinänsä koskevan paheksunnan tai hyväksynnän.

18 Haastattelusitaatteja on muokattu kirjakielisiksi.

19 Lehdissä tosin oli myös epäileviä näkemyksiä. Esimerkiksi Aamulehti kirjoitti Sata-komiteaan liittyneiden Otakantaa-verkkokeskustelujen pohjalta, että "vaikka hallitus on ottanut ohjenuoraksi köyhyyden vähentämisen, useat suomalaisista pelkäävät, että sosiaaliturvan uudistaminen johtaa päinvastaiseen tulokseen" (11.2.2008). Aamulehden pääkirjoitus 7.7.2008 puolestaan kuvasi komitean työtä näin: "Tällä tietoa uudistus ei tarkoita sitä, että sosiaaliturvaan oltaisiin sijoittamassa lisää rahaa. Pyrkimys lienee pikemminkin päinvastainen."

20 Moni haastateltu kuitenkin totesi, että vuodossa voi toisaalta olla aina kyse vain esimerkiksi toimittajalle annetusta lahjasta.

\section{Kirjallisuus}

Berger, Peter \& Luckmann, Thomas (2009). Todellisuuden sosiaalinen rakentuminen. Tiedonsosiologinen tutkielma. Helsinki: Gaudeamus. (Englanninkielinen alkuteos 1966.)

Blumler, Jay G. \& Gurevitch, Michael (1995). The Crisis of Public Communication. London: Routledge.

Brown, Robin (2011). Mediatization and news management in comparative institutional perspective. Teoksessa: Brants, Kees \& Voltmer, Katrin (toim.). Political Communication in Postmodern Democracy: Challenging the Primacy of Politics. Basingstoke: Palgrave Macmillan, 59-74.

Colyvas, Jeannette \& Powell, Walter (2006). Roads to institutionalization: The remaking of boundaries between public and private science. Research in Organizational Behavior 27, 305-353.

Cook, Timothy E. (1998). Governing with the News. The News Media as a Political Institution. Chicago: The University of Chicago Press.

Gronow, Antti (2008). Not by rules or choice alone: A pragmatist critique of institution theories in economics and sociology. Journal of Institutional Economics 4: 3, 351-373

Hallin, Daniel C. \& Mancini, Paolo (2004). Comparing Media Systems: Three Models of Media and Politics. Cambridge: Cambridge University Press.

Hannikainen, Matti \& Vauhkonen, Jussi (2012). Ansioiden mukaan. Yksityisalojen työeläkkeiden historia. Helsinki: SKS:

Herkman, Juha (2009). The structural transformation of the democratic corporatist model: The case of Finland. Javnost-The Public 16: 4, 73-90.

Hjarvard, Stig (2013). The Mediatization of Culture and Society. London and New York: Routledge.

Hodgson, Geoffrey (2006). What are institutions? Journal of Economic Issues XL: 1, 1-25.

Hodgson, Geoffrey (2007). Institutions and individuals: Interaction and evolution. Organization Studies 28: 1, 95-116.

Honkanen, Pertti \& Tervola, Jussi (2012). Vuoden 2012 perusturvamuutoksien vaikutukset. Nettityöpapereita 35/2012. Kelan tutkimusosasto. Saatavilla: helda.helsinki.fi/bitstream/handle/10138/29678/ Nettityopapereita35.pdf?sequence $=1$ (katsottu 30.4.2014)

Julkunen Raija (2001). Suunnanmuutos: 199o-luvun sosiaalipoliittinen reformi Suomessa. Tampere: Vastapaino.

Kananen, Johannes (2014). Organized business interests and social security reform: The case of corporatist policy making. Artikkelikäsikirjoitus.

Kantola, Anu (2002). Se keskustelu jäi käymättä - poliittinen eliitti ja talouskriisin julkisuus. Teoksessa: Kivikuru, Ullamaija (toim.). Laman julkisivut. Media, kansa ja eliitit 1990-luvun talouskriisissä. Helsinki: Palmenia-kustannus, 263-300. 
Kantola, Anu \& Kananen, Johannes (2013). Seize the moment: Financial crisis and the making of the Finnish competition state. New Political Economy 18: 6, 811-826.

Kernell, Sam (1997). The theory and practice of going public. Teoksessa: Iyengar, Shanto \& Reeves, Richard (toim.). Do the Media Govern? Politicians, Voters, and Reporters in America. Thousand Oaks: SAGE Publications, 323-333.

Kriesi, Hanspeter (2004). Strategic political communication: Mobilizing public opinion in "audience democracies". Teoksessa: Esser, Frank \& Pfetsch, Barbara (toim.). Comparing Political Communication: Theories, Cases and Challenges. Cambridge: Cambridge University Press, 184-212.

Kunelius, Risto; Noppari, Elina \& Reunanen, Esa (2010). Median vallan verkoissa. Toinen, korjattu painos. Julkaisuja / Sarja A 112. Tiedotusopin laitos. Tampere: Tampereen yliopisto. Saatavilla: tampub.uta. fi/handle/10024/65414

Kunelius, Risto \& Reunanen, Esa (2012). Media in political power: A parsonian view on the differentiated mediatization of Finnish decision makers. The International Journal of Press/Politics 17: 1, 56-75.

Kuutti, Heikki (toim.) (2011). Julkisuusjournalismi. Jyväskylä: Jyväskylän yliopisto, viestintätieteiden laitos.

Lawrence, Thomas; Suddaby, Roy \& Leca, Bernard (2011). Institutional work: Refocusing institutional studies of organization. Journal of Management Inquiry 20: 1, 52-58.

Lijphart, Arend (1968). The Politics of Accomodation. Pluralism and Democracy in the Netherlands. Berkeley: University of California Press.

March, James \& Olsen, Johan (1989). Rediscovering Institutions. The Organizational Basis of Politics. New York: Free Press.

Mazzoleni, Gianpetro \& Schulz, Winfried (1999). “Mediatization” of politics: A challenge for democracy? Political Communication 16: 3, 247-261.

Muuri, Anu \& Manderbacka, Kristiina (2010). Hyvinvointivaltion kannatusperusta. Teoksessa: Vaarama, Marja; Moisio, Pasi \& Karvonen, Sakari (toim.). Suomalaisten hyvinvointi 2010. Helsinki: Terveyden ja hyvinvoinnin laitos, 96-112.

Pakarinen, Auri (2011a). Tapaustutkimuksia lainvalmistelun kehittämisestä ja sääntelyn toimivuudesta. Joensuu: Itä-Suomen yliopisto.

Pakarinen, Auri (2011b). Lainvalmistelu vuorovaikutuksena. Analyysi keskeisten etujärjestöjen näkemyksistä lainvalmisteluun osallistumisesta. Oikeuspoliittisen tutkimuslaitoksen tutkimuksia 253.

Pfetsch, Barbara (2004). From political culture to political communications culture: A theoretical approach to comparative analysis. Teoksessa: Esser, Frank \& Pfetsch, Barbara (toim.). Comparing Political Communication: Theories, Cases and Challenges. Cambridge: Cambridge University Press, 344-366.

Pulkkinen, Titta (2011). Lainvalmistelijoiden näkökulma julkisuuteen. Sata-komitean lainvalmistelijoiden käsitykset julkisesta keskustelusta ja heidän julkisuuskäytäntönsä. Tiedotusopin pro gradu -tutkielma. Tampere: Tampereen yliopisto. Saatavilla: tampub.uta.fi/bitstream/handle/10024/82217/ graduo 4783 .pdf? sequence $=1$

Rainio-Niemi, Johanna (2010). State committees in Finland in historical comparative perspective. Teoksessa: Alapuro, Risto \& Stenius, Henrik (toim.). Nordic Associations in a European Perspective. Baden-Baden: Nomos Verlagsgesellschaft, 241-268.

Reunanen, Esa; Kunelius, Risto, \& Noppari, Elina (2010). Mediatization in context: Consensus culture, media and decision making in the 21st century, the case of Finland. Communications 35: 3, 287-307.

Saari, Juho (2009). Harvinainen hetki - tammikuu 2009 ja suomalaisen sosiaalipolitiikan tulevaisuus. Yhteiskuntapolitiikka 74: 3, 239-255.

Saari, Juho (2011). Sosiaaliturvan kokonaisuudistus. Tapahtumarakenneanalyysi syksystä 2007 syksyyn 2010. Teoksessa: Niemelä, Mikko \& Saari, Juho (toim.). Politiikan polut ja hyvinvointivaltion muutos. Helsinki: Kelan tutkimusosasto, 70-99.

Sabatier, Paul (1998). The advocacy coalition framework: Revisions and relevance for Europe. Journal of European Public Policy 5: 1, 98-130.

Sager, Fritz \& Rosser, Christian (2009). Weber, Wilson, and Hegel: Theories of modern bureaucracy. Public Administration Review 69: 6, 1136-1147.

Scharpf, Fritz W. (1997). Games Real Actors Play. Actor-Centered Institutionalism in Policy Research. Boulder: Westview Press.

Scott, Richard (2008). Institutions and Organizations: Ideas and Interests. 3rd edition. Thousand Oaks: Sage.

Sigal, Leon V. (1973). Reporters and Officials. The Organisation and Politics of Newsmaking. Lexington: D.C. Heath and Company. 
Soininvaara, Osmo (2010). SATA-komitea. Miksi asioista päättäminen on niin vaikeaa. Helsinki: Kustannusosakeyhtiö Teos.

Spörer-Wagner, Doreen \& Marcinkowski, Frank (2010). Is talk always silver and silence golden? The mediatisation of political bargaining. Javnost-The Public 17: 2, 5-26.

STM (2007). Sosiaaliturvan uudistamiskomitea. Asettamispäätös STMo42:00/2007. 14.6.2007.

STM (2008). Sosiaaliturvauudistuksen viestintäsuunnitelma. Viestintäyksikkö, 16.1.2008. Helsinki: Sosiaalija terveysminiteriö.

Tiitinen, Kari-Pekka (2007). Työlainsäädännön kolmikantaisesta valmistelusta. Teoksessa Orasmaa, Pekka \& Kröger, Tarja (toim.). Työoikeudellisen yhdistyksen vuosikirja 2006. Helsinki: Työoikeudellinen Yhdistys, 211-248.

Vartiainen, Juhana (2013). Työvoima tehokkaaseen käyttöön. Eli miksi työn tarjonnan lisääminen ratkaisee kestävyysvajeemme. Helsinki: Tehokkaan tuotannon tutkimussäätiö.

Weber, Max (1970a [1921]). Bureaucracy. Teoksessa: Gerth, Hans \& Mills, C. Wright (toim.). From Max Weber. Essays in sociology. London: Routledge \& Kegan Paul Ltd, 196-262. (Julkaistu alunperin v. 1921 saksankielisessä teoksessa Wirtschaft un Gesellschaft, 650-678,).

Weber, Max (1970b [1921]). Politics as a vocation. Teoksessa: Gerth, Hans \& Mills, C. Wright (toim.). From Max Weber. Essays in sociology. London: Routledge \& Kegan Paul Ltd, 196-262. (Julkaistu alunperin v. 1921 saksankielisessä teoksessa Gesammelte Politische Schriften, 396-450).

Zucker, Lynne (1991). The role of institutionalization in cultural persistence. Teoksessa Powell, Walter W. \& DiMaggio, Paul J. (toim.). The New Institutionalism in Organizational Analysis. Chicago: University of Chicago Press, 63-82. 